\title{
MiniRobots With AdAPTABLE STRUCTURE
}

\author{
TAtar, O.; AluteI, A.; MANDRU, D. \& Lungu, I.
}

Abstract: The possibilities to use robots for inspection, exploration and maintenance of the pipes are highlighted. In this paper, the authors' contribution in this field is discussed. The minirobot presented in this paper is composed of slider-crank mechanisms and uses three geared mechanisms which are driven by a DC geared motor placed in the central region of the module. For the in-pipe inspection, the minirobot uses a wireless video mini-camera fixed inside of a protection system. The control of the minirobot is achieved through a CEREBOT II circuit using a graphical interface developed using the DELPHI visual programming environment. This minirobot is used as a driving module in the modular robotic system.

Key words: minirobot, structure, adaptable, mechanism, pipe
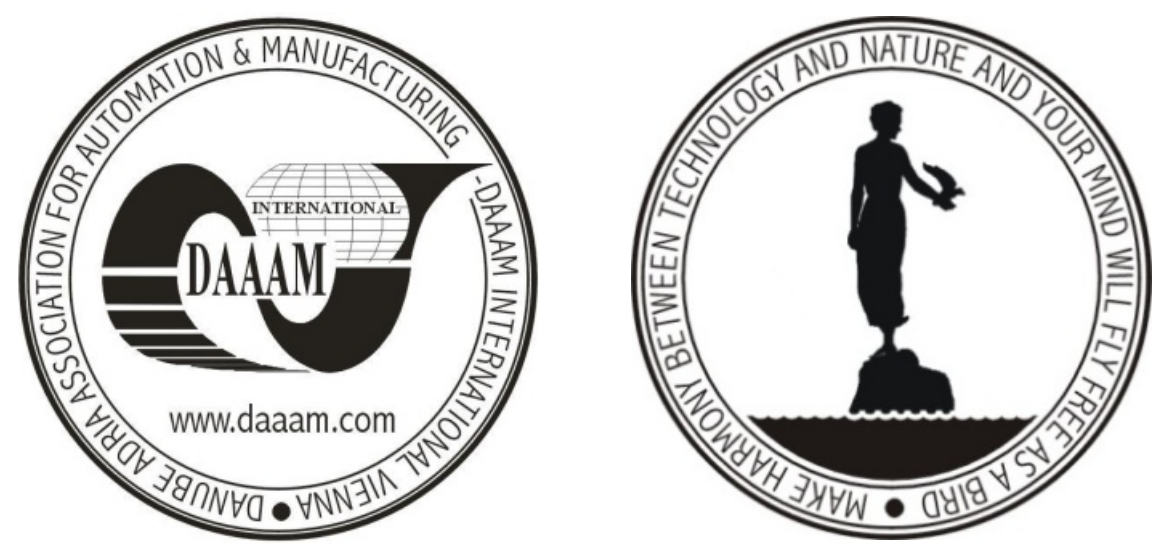

Authors' data: Assoc. Prof. Dr. Eng. Tatar, O[limpiu]; PhD. Student Eng. Alutei, A[drian]; Prof. Dr. Eng. Mandru, D[an]; PhD. Student Eng. Lungu, I[on], Technical University of Cluj-Napoca, Constantin Daicoviciu 15, 400020, ClujNapoca, Romania, olimpiut@yahoo.com, adrian.alutei@mmfm.utcluj.ro, mandrud@yahoo.com, lungu_ion@yahoo.com

This Publication has to be referred as: Tatar, O[limpiu]; Alutei, A[drian]; Mandru, D[an] \& Lungu I[on] (2009). Minirobots with Adaptable Structure, Chapter 21 in DAAAM International Scientific Book 2009, pp. 187-196, B. Katalinic (Ed.), Published by DAAAM International, ISBN 978-3-901509-69-8, ISSN 1726-9687, Vienna, Austria

DOI: $10.2507 /$ daaam.scibook.2009.21 